\title{
Rare Earths' Recovery from Phosphogypsum: An Overview on Direct and Indirect Leaching Techniques
}

\author{
Jean-Luc Mukaba *(D), Chuks Paul Eze, Omoniyi Pereao $\mathbb{B}$ and Leslie Felicia Petrik $\mathbb{C}$
}

check for updates

Citation: Mukaba, J.-L.; Eze, C.P.; Pereao, O.; Petrik, L.F. Rare Earths' Recovery from Phosphogypsum: An Overview on Direct and Indirect Leaching Techniques. Minerals 2021, 11, 1051. https://doi.org/ $10.3390 / \min 11101051$

Academic Editor: Hugo Marcelo Veit

Received: 26 August 2021

Accepted: 9 September 2021

Published: 28 September 2021

Publisher's Note: MDPI stays neutral with regard to jurisdictional claims in published maps and institutional affiliations.

Copyright: (c) 2021 by the authors. Licensee MDPI, Basel, Switzerland. This article is an open access article distributed under the terms and conditions of the Creative Commons Attribution (CC BY) license (https:// creativecommons.org/licenses/by/ $4.0 /)$.
Department of Chemistry, Environmental and Nanoscience Research, University of the Western Cape, Bellville 7535, South Africa; chupeze@gmail.com (C.P.E.); pereaokola@gmail.com (O.P.); lpetrik@uwc.ac.za (L.F.P.) * Correspondence: 3258474@myuwc.ac.za; Tel.: +27-219-593-878

\begin{abstract}
The need for rare earths elements (REEs) in high tech electrical and electronic based materials are vital. In the global economy, deposits of natural REEs are limited except for countries such as China, which has prompted current attempts to seek alternative resources of REEs. This increased the dependence on major secondary rare earth-bearing sources such as scrap alloy, battery waste, spent catalysts, fly ash, spent magnets, waste light-emitting diodes (LEDs), and phosphogypsum (PG) for a substantial recovery of REEs for use. Recycling of REEs from these alternative waste sources through hydrometallurgical processes is becoming a sustainable and viable approach due to the low energy consumption, low waste generation, few emissions, environmentally friendliness, and economically feasibility. Industrial wastes such as the PG generated from the production of phosphoric acid is a potential secondary resource of REEs that contains a total REE concentration of over $2000 \mathrm{mg} / \mathrm{kg}$ depending upon the phosphate ore from which it is generated. Due to trace concentration of REEs in the PG (normally $<0.1 \% \mathrm{wt}$.) and their tiny and complex occurrence as mineral phases the recovery process of REE from PG would be highly challenging in both technology and economy. Various physicochemical pre-treatments approaches have been used up to date to up-concentrate REEs from PG prior to their extraction. Methods such as carbonation, roasting, microwave heating, grinding or recrystallization have been widely used for this purpose. This present paper reviews recent literature on various techniques that are currently employed to up-concentrate REs from PG to provide preliminary insight into further critical raw materials recovery. In addition, the advantages and disadvantages of the different strategies are discussed as avenues for realization of REE recovery from PG at a larger scale. In all the different approaches, recrystallization of PG appears to show promising advantages due to both high REE recovery as well as the pure PG phase that can be obtained.
\end{abstract}

Keywords: rare earths; phosphogypsum; acid leaching; bioleaching; recrystallization; carbonation

\section{Introduction}

Rare earths elements (REEs) are metals of the lanthanoids series on the periodic table commonly referred to as lanthanides, with atomic numbers ranging from 57 to 71 . The REEs are usually classified in sub-groups as light (lanthanum to europium) or heavy (gadolinium to lutetium) based on their relative atomic weights [1]. Although, REEs have similar chemical properties, each individual REE displays unique characteristics and generally can not be substituted for specific applications [2]. The field of REE applications is extensive and their demand is high and mainly dominated by the magnetic, catalytic, metallurgical and polishing industries as shown in Figure 1 [3]. From their initial time of discovery, the utilization of REEs has developed from mischmetal to high purity separated REE metal used in current advanced technologies. This advancement has consequently led to a strong growth in the use of rare earth oxides (REOs) in the past few decades, from 75,500 tons reported in 2000 to 123,100 tons in 2016 and 167,500 tons in 2017 [4,5]. The mining and production of REOs have been dominated by China since 1990 and most of the 
countries where these metals are part of the important innovation technologies depend on importations from China [6,7]. However, the past two decades have seen a rapid growth in the manufacturing industries in China ranking it among the major consumers of REEs, which has resulted in reduced yearly export quotas from China to other parts of the world [8]. REE supply and availability is therefore described to be at risk due to the current state of affairs, where China controls over $90 \%$ of REE production worldwide [9]. The Chinese control over the annual amounts of REO had led to significant price fluctuations, in particular for elements such as neodymium, dysprosium, europium, yttrium and terbium that are mostly used in sustainable applications. This control has prompted an urgent search for new deposits of REEs as well as the reopening of formerly exploited deposits such as the Mountain Pass mine in Nevada, United States of America, which was reopened in 2012 [7]. However, the search for new REE deposits or reopening of formerly existing REE mines is economically costly and alternative sources of these metals are needed to compensate for both the current scarcity and cost associated with conventional mining as the use of REEs is expected to increase and supply will affect several innovative areas in future $[10,11]$. Several studies have recently been carried out to investigate the feasibility of extracting REEs through recycling of low value waste streams such as bauxite residue, mine tailings, PG, slag and waste waters [12-14]. Amongst the aforementioned waste streams, PG has been identified as a promising source of REEs (Table 1) [15-17]. Despite the low concentration of REEs in PG when compared to primary REE bearing minerals such as monazite [18], the large volumes of PG, currently estimated to be 200-300 million tons per annum, makes it a potential source of REEs [19]. Furthermore, the extraction and recovery of REEs from PG has several advantages over conventional mining such as avoiding the costs of mining and its related infrastructure that are almost absent [18]. The low concentration of REEs in the PG and their occurrence as complex mineral phases could cause the extraction of REEs from PG to be highly challenging in both technology and economy. This paper therefore intends to review the progress achieved in the past 20 years regarding REE up-concentration from PG prior to their respective extraction and recovery by examining various approaches.

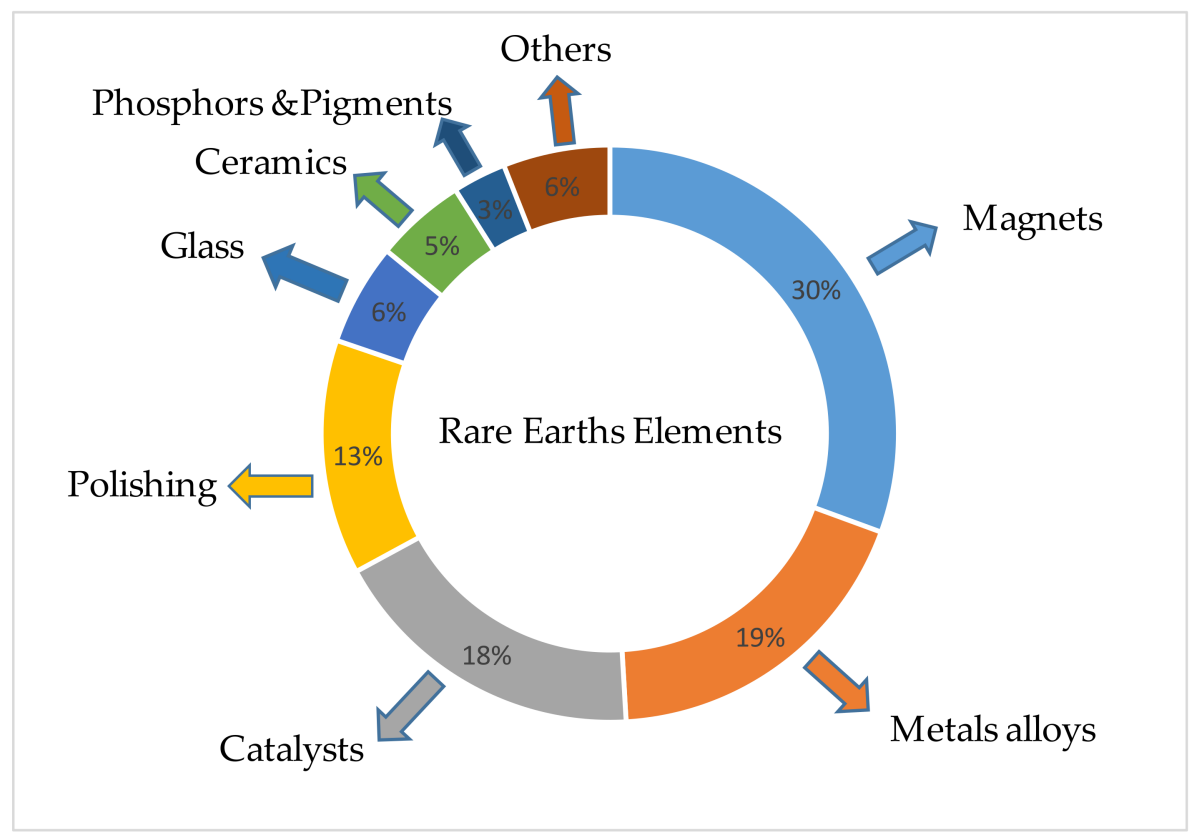

Figure 1. Estimation of global REE demand by applications in 2017 (adapted and modified from [3]). 
Table 1. REE content from various recycling waste streams (ppm).

\begin{tabular}{|c|c|c|c|c|c|c|c|c|c|c|c|c|c|c|c|c|c|}
\hline \multirow{2}{*}{ Bearing Wastes } & \multicolumn{16}{|c|}{ REEs } & \multirow{2}{*}{ Ref } \\
\hline & La & $\mathrm{Ce}$ & $\operatorname{Pr}$ & $\mathrm{Nd}$ & $\mathrm{Sm}$ & Eu & $\mathrm{Gd}$ & $\mathrm{Tb}$ & Dy & Ho & Er & $\operatorname{Tm}$ & $\mathbf{Y b}$ & Lu & $\mathbf{Y}$ & $\mathrm{Sc}$ & \\
\hline Acid mine drainage & 0.9 & 0.09 & 0.03 & 0.1 & 0.06 & 0.02 & 0.1 & 0.02 & 0.07 & 0.01 & 0.03 & 0.002 & 0.01 & 0.002 & NR & NR & [19] \\
\hline Fly ash & 91 & 196 & 24 & 89 & 18 & 3 & 16 & 3 & 13 & 3 & 7 & 1 & 7 & 1 & 62 & NR & [20] \\
\hline Mine tailings & 903 & 2047 & 239 & 906 & 148 & 19 & 138 & 16 & 101 & 17 & 54 & 5 & 38 & 4 & 664 & NR & [21] \\
\hline NdFeB magnet & NR & NR & 3 & 260 & NR & NR & NR & NR & 42 & NR & NR & NR & NR & NR & NR & NR & [22] \\
\hline NiMH batteries & 237 & 67 & NR & 36 & NR & NR & NR & NR & NR & NR & NR & NR & NR & NR & NR & NR & [23] \\
\hline Phosphogypsum & 1450 & 2310 & 235 & 899 & 163 & 35 & 99 & 7 & 46 & 7 & 16 & 1 & 6 & 0.6 & 180 & 1 & [24] \\
\hline Phosphor & 4 & 5 & NR & NR & NR & 3 & 3 & NR & NR & NR & NR & NR & NR & NR & 112 & NR & [25] \\
\hline
\end{tabular}

\section{Phosphogypsum}

Phosphogypsum (PG) is the chemical gypsum or by-product generated during the processing of phosphate ores (fluorapatite, $\left.\mathrm{Ca}_{5}\left(\mathrm{PO}_{4}\right)_{3} \mathrm{~F}\right)$ in acidic medium [11]. The names of the chemical gypsums are usually derived from its primary manufacturing products created during the chemical processing. For instance, phosphogypsum, phenologypsum and borogypsum are respectively by-products from phosphoric acid, phenol and boric acid processing [26]. For phosphogypsum $\left(\mathrm{CaSO}_{4} \cdot 2 \mathrm{H}_{2} \mathrm{O}\right)$, the reaction involves a concentrate of $\mathrm{Ca}_{5}\left(\mathrm{PO}_{4}\right)_{3} \mathrm{~F}$ which is dissolved in a mixture of sulphuric acid $\left(\mathrm{H}_{2} \mathrm{SO}_{4}\right)$ to produce phosphoric acid along with other products as described in Equation (1).

$$
\mathrm{Ca}_{5}\left(\mathrm{PO}_{4}\right)_{3} \mathrm{~F}(\mathrm{~s})+5 \mathrm{H}_{2} \mathrm{SO}_{4}(\mathrm{a})+10 \mathrm{H}_{2} \mathrm{O}_{(\mathrm{a})} \rightarrow 3 \mathrm{H}_{3} \mathrm{PO}_{4(\mathrm{a})}+5 \mathrm{CaSO}_{4} \cdot 2 \mathrm{H}_{2} \mathrm{O}(\mathrm{s})+\mathrm{HF}(\mathrm{a})
$$

The phosphoric acid obtained in this process is mainly used in the production of phosphorus fertilizer while hydrofluoric acid is recycled in acidic process waters [27]. Hence, for each ton of phosphoric acid produced, about 1.7 tons of PG can be produced as a precipitate. Phosphate ore used in this process usually contains $20-40 \%$ of phosphate and the balance constitutes the impurities that mainly include aluminium dioxide, calcium oxide, carbon dioxide, fluorine, silicon dioxide, sodium dioxide, sulphur trioxide, iron oxide, magnesium oxide; heavy metals, $\mathrm{U}$, Th and REEs. Of these impurities, REE content varies between $0.1-2$ wt. \% of which $70-95 \%$ gets concentrated into PG $[24,28]$. However, depending upon both the source of phosphate ores and the processing method, the concentration of REEs in PG can vary. For instance, the concentrations of REEs present in PG obtained through dehydrate (DH) and hemihydrate $(\mathrm{HH})$ processes originating from America, Belgium, Brazil, Canada, Egypt, Poland, Russia, and Tunisia were found varying between 0.01 and 0.6 wt. \% as shown in Table 2. However, it is important to highlight that, in a process where PG-HH is produced, almost $90-95 \%$ of the REEs can be transferred to PG waste, whereas only $70-80 \%$ is transferred in the PG-DH method $[28,29]$. Phosphoric acid processing associated with the production of PG-DH has globally been the most frequently used in recent years compared to a few processes where PG-HH is produced [28]. Therefore, the present paper will mainly focus on PG-DH generated from phosphoric acid processing.

Table 2. REE content from various types of phosphogypsum.

\begin{tabular}{cccc}
\hline Country of Origin & Type of PG & REO Content (\% wt) & Ref \\
\hline America & $\mathrm{DH}$ & 0.034 & {$[30]$} \\
Belgium & $\mathrm{DH}+\mathrm{HH}$ & 0.55 & {$[24]$} \\
Brazil & $\mathrm{DH}$ & $0.52-0.54$ & {$[31]$} \\
Canada & $\mathrm{DH}$ & 0.02 & {$[32]$} \\
Egypt & $\mathrm{DH}$ & 0.048 & {$[33]$} \\
Poland & $\mathrm{DH}+\mathrm{HH}$ & $0.11-0.65$ & {$[16]$} \\
Russia & $\mathrm{DH}$ & 0.47 & {$[34]$} \\
Russia & $\mathrm{HH}$ & $0.40-0.43$ & {$[34]$} \\
Russia & $\mathrm{HH}$ & 0.59 & {$[35]$} \\
Russia & $\mathrm{HH}$ & 0.11 & {$[35]$} \\
Russia & $\mathrm{HH}$ & 0.46 & {$[36]$} \\
Russia & $\mathrm{DH}+\mathrm{HH}$ & $0.3-0.9$ & {$[37]$} \\
Tunisia & $\mathrm{DH}$ & 0.022 & \\
\hline
\end{tabular}




\section{Phosphogypsum Disposal and Use Worldwide}

The disposal of PG requires large land areas where it can be stacked. To date, more than a billion tons of PG has been produced and stockpiled on land worldwide leading to landfill issues [38]. Severe environmental problems have resulted due to the leaching of radioactive elements such as $\mathrm{U}, \mathrm{Ra}, \mathrm{Th}$ as well as heavy metals such as $\mathrm{Cd}, \mathrm{Ni}$ [28]. These elements are known to percolate into groundwater and soils and cause contamination due to the long-term storage [39]. Furthermore, in some countries where phosphoric acid is produced such as Morocco, Mexico, Tunisia and South Africa, PG waste is directly poured into the ocean [40]. In an attempt to utilise such a huge amount of PG, several studies have focused on transferring PG into building materials, ammonia fertilizer and soil amendments [41]. However, over $85 \%$ of PG annually generated worldwide is disposed of on land or sea and only 15\% is utilised in recycling processing such as building materials (plaster, wallboard etc.), soil stabilisation amendments or fertilizers or manufacturing of Portland cement (settling time controller) [42]. This is mainly due to some specific limitations of impurities such as radioactive and REEs being present in PG [43]. A few studies have investigated the phases in which REEs occurred in PG but their conclusions varied depending upon the source of the PG [44-46]. From these studies, it was found that REEs usually occur in four main phases namely as carbonates, phosphates, fluorides, and sulphates. The first two phases are usually referred to as associated phases and the last two as replacement phases for calcium in the crystal lattice structure. REEs found as associated mineral phases are readily soluble using mineral acids such as $\mathrm{HCl}, \mathrm{H}_{2} \mathrm{SO}_{4}$ and $\mathrm{HNO}_{3}$ while those in replacement phases require treatment processes to increase both chemical and physical reactivity of PG. However, apart from these phases, REEs can also be found as adsorbed ions in PG. REE occurrences in PG were recently investigated by Yang et al. [47] by combining mineral liberation analysis (MLA) and electron microprobe analysis (EMA) for mineral analysis and ICP-MS for elemental composition. Their results showed that gypsum $\left(\mathrm{CaSO}_{4}\right)$ was the dominating mineral phase in PG that contained over $72 \%$ of REEs present in the samples.

\section{Beneficiation Methods}

Physical and chemical pre-treatment methods have been used to upgrade the low concentrations of REEs present in PG prior to processing. Physical methods such as hydrodynamic, flotation, grinding and high gradient magnetic separation (HGMS) have been reported in the literature [46,47]. In a study by Yang et al. [48] four tests of physical enrichments were conducted on PG through treating it by HGMS alone, flotation combined with HGMS or mechanical grinding followed by flotation and HGMS, and hydrodynamic sedimentation followed by HGMS, respectively. Their results proved that PG was effectively enriched in REEs from an initial grade of 0.13 to $7.3 \mathrm{wt}$. \%. In another trial, the authors used a centrifugal ball milling at 30,60 and $90 \mathrm{~min}$ prior to the leaching process in a suspension of $\mathrm{HCl}$ or $\mathrm{HNO}_{3}$. The results clearly showed that the milling had a significant effect on the extractability efficiencies of REEs as, in the samples milled, the extracted REEs increased for all the REEs as the milling time increased. According to these authors, this improvement of REE leaching efficiency using mechano-activation by grinding could be attributed to increased specific area and decreased virtual activation energy of ground material due to crystal interior defects. However, the recovery of individual elements differed because REEs in PG are carried by the gypsum mineral phase which was not completely enriched by the aforementioned physical methods. Therefore, the loss of REEs during the beneficiation process mainly resulted from that portion remaining in the gypsum. Microwave radiation has also been used by Reid et al. [49] and Lambert et al. [50] for enrichment of PG prior to REE leaching. It was found that microwaving PG resulted in dielectric heating of water molecules present in PG crystals causing the formation of pores in the PG matrix as the water vapour escaped. Chemical enrichment approaches have also been discussed by Hammas-Nasri et al. [51]. In their study the PG was treated consecutively with solutions of $\mathrm{NaCl}$ and $\mathrm{Na}_{2} \mathrm{CO}_{3}$ in an attempt to enrich the PG with REEs in the final 
residue prior to the leaching process. Their methods consisted of washing $500 \mathrm{~g}$ of PG with 25 or $60 \mathrm{~g} / \mathrm{L}$ saline $\mathrm{Na}_{2} \mathrm{CO}_{3}$ solutions ( $\mathrm{S}: \mathrm{L}=1: 200$ ) resulting in approximately $81 \%$ and $84 \%$ increased rates of enrichment, respectively. Improvement of REE leaching from PG, through investigating the effects of mechanical treatments (grinding and ultrasonic impact) and chemical activation (sorption onto an ion exchange resin) were also reported by Rychkov et al. [17]. The study consisted of treating $40 \mathrm{~g}$ of PG with $300 \mathrm{~mL}$ of $\mathrm{H}_{2} \mathrm{SO}_{4}$ ( $\mathrm{S}: \mathrm{L}=1: 7.5$ ) and it was found that upon exposure to highly concentrated $\mathrm{H}_{2} \mathrm{SO}_{4}$, only $30 \%$ of REEs present in the PG was leached. The authors explained this low recovery was a result of strong chemical bonding between the REEs and the crystals of PG. Nevertheless, by applying grinding and ultrasonic impact treatment simultaneously in an attempt to reduce the particle size to between 6 and $8 \mu \mathrm{m}$ while adding a strong acid cation exchange resin (Purolite C-160) directly to the $\mathrm{H}_{2} \mathrm{SO}_{4}$ leaching solution, the REE recovery was found to increase by a factor of 4 . Moreover, by sorbing the REE ions directly from the leaching solution onto the strong acid cation exchange resin, the potential for precipitating the REEs as double sulphate and oxide complexes was minimized. The proposed process was able to increase REE recovery from $15-17 \%$ to over $70 \%$ by physical and chemical reactivity of the PG, which also led to a PG product containing less impurities. Although physical and chemical treatments of PG are promising approaches towards high leaching efficiencies of REEs, they involve additional costs particularly at large scale. To overcome this, PG could also be treated directly through hydrometallurgical processing such as direct and indirect leaching, without physical and chemical pre-treatments due to its smaller particle size [42].

The leaching is the first step in the hydrometallurgical process in which the operational parameters such as agitation speed, contact time (residence time), particle size, solid to liquid ratio (S:L), lixiviant type, and temperature are usually varied to obtain optimum conditions [52]. The leaching of PG is mainly possible as most REEs occur as adsorbed secondary phases onto the surface of PG. This surface adsorption suggests that REEs should be relatively susceptible to be extracted through aqueous chemical agents such as inorganic or organic liquids, compared to a case where REE are found incorporated within the crystal lattice of PG [53].

\subsection{Direct Leaching}

Strong inorganic acids such as $\mathrm{H}_{2} \mathrm{SO}_{4}, \mathrm{HCl}$ and $\mathrm{HNO}_{3}$ are the most commonly used lixiviants in direct leaching of PG due to their strength and availability (Table 3). However, the leaching efficiency of REEs from PG is limited by the solubility of the gypsum $\left(\mathrm{CaSO}_{4}\right)$ in the system. Thus, as $\mathrm{CaSO}_{4}$ reaches its solubility limit, no additional REEs can leach since the remaining REEs are trapped inside the undissolved PG particles. According to Kouraim et al. [54], the possible chemical reactions that can occur during the leaching of $\mathrm{PG}$ with $\mathrm{HCl}, \mathrm{HNO}_{3}$ or $\mathrm{H}_{2} \mathrm{SO}_{4}$ can be described as indicated in Equations (2)-(4).

$$
\begin{gathered}
\mathrm{XCaSO}_{4}-\mathrm{REE}_{(\mathrm{s})}+\mathrm{yHNO}_{3} \rightarrow(\mathrm{x}-\mathrm{n}) \mathrm{CaSO}_{4}+\mathrm{nCa}\left(\mathrm{NO}_{3}\right)_{3}+\mathrm{nREE}(\mathrm{s})\left(\mathrm{NO}_{3}\right)_{3}+\mathrm{nH}^{+} \\
\mathrm{XCaSO}_{4}-\mathrm{REE}_{(\mathrm{s})}+\mathrm{yHCl} \rightarrow(\mathrm{x}-\mathrm{n}) \mathrm{CaSO}_{4}+\mathrm{nCaCl}_{2}+\mathrm{nREE}_{(\mathrm{s})} \mathrm{Cl}_{3}+\mathrm{nH}^{+} \\
\mathrm{XCaSO}_{4}-\mathrm{REE}_{(\mathrm{s})}+\mathrm{yH}_{2} \mathrm{SO}_{4} \rightarrow(\mathrm{x}-\mathrm{n}) \mathrm{CaSO}_{4}+\mathrm{nCaSO}_{4}+\mathrm{n}\left(\mathrm{REE}_{(\mathrm{s})}\right)_{2}\left(\mathrm{SO}_{4}\right)_{3}+\mathrm{nH}^{+}
\end{gathered}
$$

In general, $\mathrm{H}_{2} \mathrm{SO}_{4}$ leaching is economically advantageous due to its much lower cost and therefore is mostly used. However, the key obstacle encountered with $\mathrm{H}_{2} \mathrm{SO}_{4}$ direct leaching of PG for REE extraction, is the inefficient diffusion of proton, sulphate ions and REE ions between the layers of calcium sulphate crystals to which calcium ions are tightly bonded. This effect was attributed to low solubility of PG in $\mathrm{H}_{2} \mathrm{SO}_{4}$ solution resulting from the common-ion effect [32]. For instance, under normal conditions of temperature and pressure, only low leaching efficiencies ranging from $12-40 \%$ have been attained [28]. Liang et al. [55] recently studied the extraction of REEs from PG (total REE concentration estimated at $218.42 \mathrm{ppm}$ ) generated at Mosaic Co. in Florida using $5 \% \mathrm{H}_{2} \mathrm{SO}_{4}$, at S:L ratio of 1:4 (300 g of PG per experiment) at a temperature of $50{ }^{\circ} \mathrm{C}$ for $120 \mathrm{~min}$. Their results showed that a maximum leaching efficiency of $43 \%$ REE was obtained with increased 
contact time and S:L ratios. However, the leaching of the impurities such as $\mathrm{U}, \mathrm{F}$ and $\mathrm{P}$ also increased. In order to enhance the leaching efficiency, a few other approaches have been considered.

Ammas-Nasri et al. [37] conducted a study on REE recovery from PG using a double $\mathrm{H}_{2} \mathrm{SO}_{4}$ leaching step to enhance REE dissolution. In their study about $500 \mathrm{~g}$ of PG containing a total REE concentration of about 224.93 ppm was leached with $\mathrm{H}_{2} \mathrm{SO}_{4}$ solutions $(\mathrm{S}: \mathrm{L}=1: 1.3)$. The results showed a high enrichment of REEs of about $86 \%$ ( $\Sigma$ REE concentration of $1671.89 \mathrm{ppm}$ ) in the crystallised solid obtained from the evaporation of the second leachate, which was a mixture of anhydrite-monetite $\left.\left(\mathrm{CaSO}_{4}-\mathrm{CaHPO}\right)_{4}\right)$ phases. Notwithstanding the enrichment of REEs obtained in this approach, the evaporation process was energy consuming when considering scaling up the process. The evaporation of the leachate exerts a beneficial influence on the isolation of REEs from PG but the incurred costs related to the heating of the solution dominates among the production costs rendering the process unprofitable. Lokshin et al. [56] extended the leaching time to several weeks in an attempt to increase the REE extraction efficiency using a $\mathrm{H}_{2} \mathrm{SO}_{4}$ solution. In their investigation, $40 \mathrm{~g}$ of $\mathrm{PG}$ was leached with $\mathrm{H}_{2} \mathrm{SO}_{4}$ solutions (0.5-4 wt. \%) for $3025 \mathrm{~h}$ (18 weeks) using a $S: L$ ratio of 1:2. However, the leaching efficiency of REEs only increased by three times compared to the case where $1 \mathrm{~h}$ leaching was used under the same conditions. Other methods such as that developed at Prayon SA in Engis, Belgium, consisted of extracting the REEs from a diluted $\mathrm{H}_{2} \mathrm{SO}_{4}$ solution while stirring the suspension at a high speed of $6000 \mathrm{rpm}$ and subsequent recovery of REEs using organic extractants in a solvent extraction process or precipitation with oxalic acid [24]. Valkov et al. [57] also reported an increased yield of REEs while leaching $50 \mathrm{~g}$ of PG using bubbling of air into the $\mathrm{H}_{2} \mathrm{SO}_{4}$ pulp at a temperature of $70-100{ }^{\circ} \mathrm{C}$ for $1-2 \mathrm{~h}$ and $\mathrm{S}: \mathrm{L}$ of 1 . Although the authors indicated that the residue of PG was environmentally friendly for applications such as road constructions, no percentage yield of REEs was given. Similar to $\mathrm{H}_{2} \mathrm{SO}_{4}$, the leaching of REEs from PG was also found to be moderately low with $\mathrm{HCl}$. The low leaching of $\mathrm{HCl}$ was mainly attributed to the relatively low solubility of calcium sulphate in the $\mathrm{HCl}$ solution because of the salt out effect that is associated with this process [32]. However, Ismail et al. [33] demonstrated that REE fluorides were obtained by $\mathrm{HCl}$ leaching of PG after the REEs were partially precipitated into the residue.

$\mathrm{HNO}_{3}$ leaching of REEs from PG seems the most efficient compared to $\mathrm{H}_{2} \mathrm{SO}_{4}$ and $\mathrm{HCl}$ due to the relative higher solubility of calcium sulphate in $\mathrm{HNO}_{3}$ solution. The leaching efficiency of REEs with $\mathrm{HNO}_{3}$ can reach up to $50 \%$ when using a low S:L ratio. A study conducted on Egyptian PG by El-Reefy et al. [58] using a mixture of $\mathrm{HNO}_{3}(2.0-3.0 \mathrm{M})$ and $0.8 \mathrm{M}$ calcium nitrate for $8 \mathrm{~h}$ residence time and varying the $\mathrm{S}: \mathrm{L}$ ratios showed that the leaching efficiency of REEs increased with increasing S:L ratio but decreased with low $S: L$ ratios under the same conditions. Similar patterns were observed by Ismail et al. [33] where the temperature effect was investigated. Lokshin et al. [59], reported a high leaching efficiency of REEs up to $93 \%$ using $15 \mathrm{wt} \% \mathrm{HNO}_{3}$ concentration and S:L ratio 1:10. It was found that with a high S:L ratio, the leaching efficiency of REEs increased with increasing the concentration of $\mathrm{HNO}_{3}$ below $15 \%$ wt and decreased gradually with continuous increasing of the concentration from $15 \%$ wt and above. However, while leaching REEs and calcium ions from PG (S:L = 1:8) obtained at the Agrium fertilizer plant, only a slight improvement of $6 \%$ on the leaching efficiency of REEs and $29 \%$ for calcium were reached when increasing the $\mathrm{HNO}_{3}$ concentration from 1.5 to $3.0 \mathrm{M}$ [32]. Despite the fact that $\mathrm{HNO}_{3}$ is reported to have moderately high leaching efficiencies compared to $\mathrm{HCl}$, the latter is more economical and can be potentially considered as a better leaching agent of REEs from PG from an industrial point of view. Although a few moderate REE leaching efficiencies have been reported through direct leaching of PG, so far these methods have been deemed uneconomical especially for larger scales [60]. Furthermore, due to the limited solubility of PG, dissolving it completely in an attempt to recover only REEs is neither economical nor practically feasible as the concentration of REE to be extracted is low. Therefore, exploring technologies that involve indirect leaching of REEs such as 
carbonation and recrystallization of PG for production of materials that have commercial and industrial utilization with subsequent extraction of REEs is advisable.

\subsection{Indirect Leaching}

In contrast to direct leaching, indirect leaching refers here to processes that consist of modifying the microstructure of PG into materials that could find commercial and industrial applications while releasing locked REEs. Processes such as carbonation and recrystallization of PG offer good potentiality to achieve such an approach. Applying such processes can render the extraction of REEs more economical and attractive due to high REE content in PG estimated at about 21 million tons as well as saleable products that can be obtained for industrial and commercial utilization [61]. Therefore, the following sections mainly discuss the development that has been performed so far in respect of the aforementioned approaches with a particular attention on the mild acid recrystallization of PG for the fabrication of calcium whiskers and subsequent recovery of REEs from PG.

\subsubsection{Carbonation}

The carbonation process is one of the approaches that can be explored for the valorisation of PG by converting it to calcium carbonate $\left(\mathrm{CaCO}_{3}\right)$ or ammonia sulphate (AS) fertilizer and has been widely described in the literature [62,63]. Pure $\mathrm{CaCO}_{3}$ can be used in a wide range of commercial and industrial applications such as for the manufacturing of concrete (Portland cement) and production of lime (soil stabilization and acid neutralization), water treatment and flue gas desulfurization [64]. $\mathrm{CaCO}_{3}$ produced from PG processing has been found to be richly concentrated in REEs originally present in the PG waste [65]. This processing is therefore considered as an interesting method of up-concentrating REE prior to their recovery through dissolution of $\mathrm{CaCO}_{3}$ using mineral acids followed by extraction [62]. However, as schematically presented in Figure 2, PG carbonation as such is generally used for the production of $\mathrm{AS}$ and both $\mathrm{CaCO}_{3}$ and REEs are usually obtained as intermediate products from this process [66].

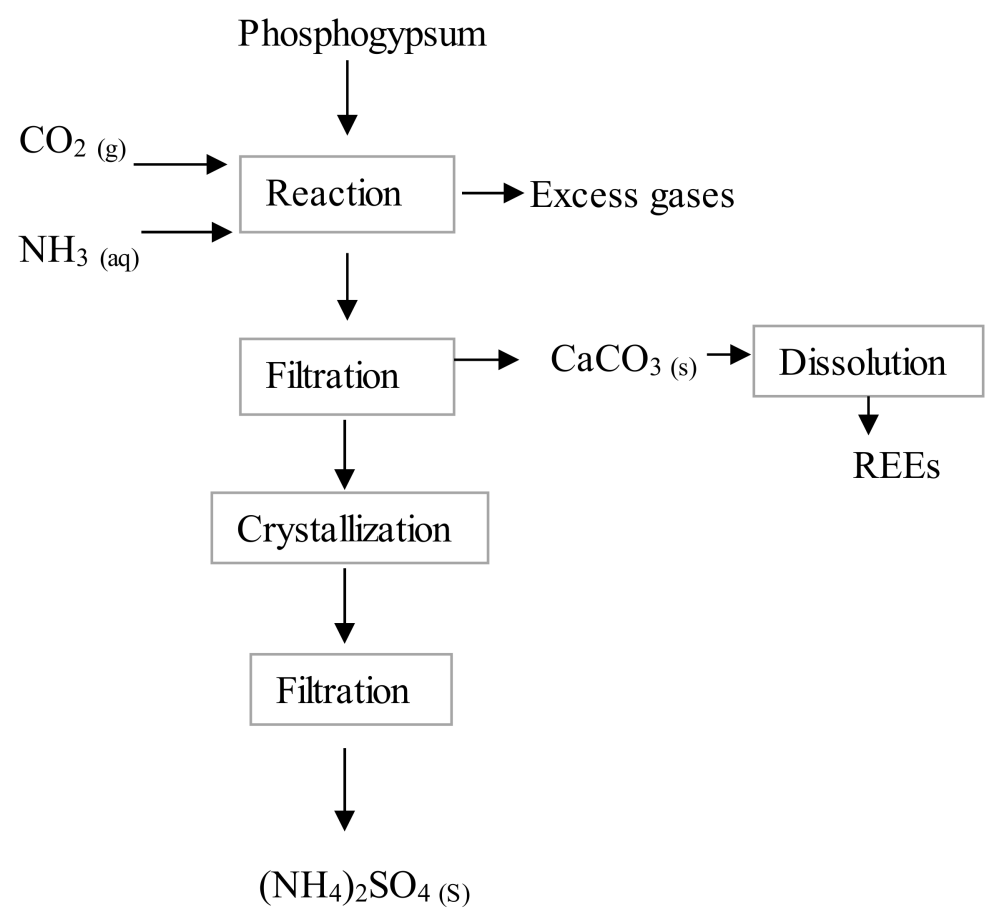

Figure 2. Mineral carbonation of phosphogypsum adapted and modified from [66]. 
Table 3. Leaching efficiencies of REEs from PG using various leaching agents.

\begin{tabular}{|c|c|c|c|c|c|c|c|}
\hline Approach & $\begin{array}{l}\text { REE Content } \\
\text { (wt. \%) }\end{array}$ & Lixiviant & S:L Ratio & Time (h) & Temperature $\left({ }^{\circ} \mathrm{C}\right)$ & Efficiency (\%) & Ref \\
\hline \multirow{19}{*}{$\begin{array}{l}\text { Inorganic acid } \\
\text { leaching }\end{array}$} & 0.041 & $15 \% \mathrm{H}_{2} \mathrm{SO}_{4}$ & $1: 3$ & 2 & 100 & 60 & [67] \\
\hline & 0.035 & $3 \mathrm{M} \mathrm{HNO}_{3}$ & $1: 30$ & 8 & 25 & 85 & [11] \\
\hline & $0.17^{*}$ & $2.5 \% \mathrm{HNO}_{3}$ & $1: 7.5$ & 0.25 & 25 & 59 & [68] \\
\hline & 0.032 & $1.5 \mathrm{M} \mathrm{HCl}$ & $1: 15$ & 1 & 85 & $\begin{array}{c}\text { Nd: } 80 \\
\text { Dy: } 99 \\
\text { Y: } 99\end{array}$ & {$[50]$} \\
\hline & 2.6 & $\mathrm{H}_{2} \mathrm{SO}_{4}$ & $1: 6$ & 4.3 & 275 & 95 & [18] \\
\hline & 0.19 & $0.01 \mathrm{M} \mathrm{H}_{2} \mathrm{SO}_{4}$ & $1: 20$ & $20-22$ & 24 & 15 & [68] \\
\hline & 0.44 & $10 \% \mathrm{H}_{2} \mathrm{SO}_{4}$ & $1: 3$ & 20 & 2 & 52 & [69] \\
\hline & 1.7 & $1 \mathrm{~g} / \mathrm{L} \mathrm{H}_{2} \mathrm{SO}_{4}$ & $1: 8$ & 24 & - & $45-75$ & [70] \\
\hline & 0.44 & $10-30 \% \mathrm{H}_{2} \mathrm{SO}_{4}$ & $1: 7.5$ & 2 & 50 & 72 & [17] \\
\hline & 0.022 & $10 \% \mathrm{H}_{2} \mathrm{SO}_{4}$ & $1: 1.3$ & $1-2$ & 60 & 50 & [37] \\
\hline & & $1.5 \mathrm{M} \mathrm{HCl}$ & & & & 51 & \\
\hline & 0.020 & $1.5 \mathrm{M} \mathrm{H}_{2} \mathrm{SO}_{4}$ & $1: 8$ & 0.33 & 80 & 23 & [32] \\
\hline & & $1.5 \mathrm{M} \mathrm{HNO}_{3}$ & & & & 57 & \\
\hline & 0.042 & $36 \% \mathrm{HNO}_{3}$ & $1: 4$ & 1 & 72 & 58 & Г201 \\
\hline & 0.034 & $90 \% \mathrm{H}_{2} \mathrm{SO}_{4}+10 \% \mathrm{H}_{3} \mathrm{PO}_{4}$ & $1: 6.7$ & 1 & 72 & 49 & [30] \\
\hline & & $3 \mathrm{M} \mathrm{HNO}_{3}$ & & & & 43 & \\
\hline & 0.048 & $2 \mathrm{M} \mathrm{HCl}$ & $1: 2$ & 3 & 25 & 12 & [33] \\
\hline & & $4 \mathrm{M} \mathrm{H}_{2} \mathrm{SO}_{4}$ & & & & 13 & \\
\hline & 0.048 & $1 \mathrm{M} \mathrm{C}_{6} \mathrm{H}_{8} \mathrm{O}_{7}$ & $1: 5$ & 0.25 & 85 & 83.4 & [71] \\
\hline \multirow{2}{*}{ Organic leaching } & \multirow{2}{*}{0.040} & $0.7 \mathrm{M}$ TBP- $0.9 \mathrm{M}$ TOPO & $1: 1$ & 2 & 55 & 70 & \multirow{2}{*}{ [72] } \\
\hline & & $0.5 \mathrm{M} \mathrm{Na}_{2} \mathrm{CO}_{3}+$ TPB-TOPO & $1: 1$ & 2 & 55 & 80 & \\
\hline \multirow{6}{*}{ Bioleaching } & \multirow{6}{*}{1.3} & & \multirow{6}{*}{$1: 50$} & \multirow{6}{*}{24} & \multirow{6}{*}{25} & Y: 91.2 & \multirow{6}{*}[53]{} \\
\hline & & Spent medium & & & & Ce:36.7 & \\
\hline & & $\begin{array}{l}\text { (Gluconobacter oxydans, } 220 \\
\text { mM gluconic acid) }\end{array}$ & & & & Nd: 42.8 & \\
\hline & & Gluconobacter oxydants & & & & Sm: 73.2 & \\
\hline & & NRRL, B85 & & & & Eu: 50 & \\
\hline & & & & & & Yb: 83.7 & \\
\hline
\end{tabular}

Note: * $(\mathrm{mg} / \mathrm{kg})$.

Masmoudi-Soussi et al. [43] recently developed a hydrothermal method that consisted of converting PG to $\mathrm{CaCO}_{3}$ using a high-pressure and high-temperature Parr-reactor. Prior to the conversion, $\mathrm{PG}$ was washed with salt water $(\mathrm{NaCl} / 25 \mathrm{~g} / \mathrm{L})$. The results were obtained at $80-100{ }^{\circ} \mathrm{C}$ for $2 \mathrm{~h}$, and showed that the hydrothermal conversion was effective and led to a complete conversion of the sulphate matrix of PG to the corresponding carbonate, which was enriched in REEs at a rate of $66 \%$. The authors indicated that the enrichment was related to the insertion of the REEs into the gypsum matrix by replacement of calcium ions in the PG as well as the known affinity of REEs towards carbonates in an alkaline $\mathrm{pH}$. The leaching of the obtained carbonate using $\mathrm{HCl}$ solution $(5-6 \%)$ at $80-90^{\circ} \mathrm{C}$ for an hour in the presence of ascorbic acid as a reducing agent, allowed the migration of about $89 \%$ of REEs to the acid liquor. In a parallel approach, PG can also be directly decomposed by reaction with ammonium carbonate as shown in Equation (5). This decomposition is carried out in order to form AS fertiliser and $\mathrm{CaCO}_{3}$ and as in the aforementioned approaches, REEs report significantly to $\mathrm{CaCO}_{3}$ solid. Thus, the dissolution of $\mathrm{CaCO}_{3}$ in $\mathrm{HNO}_{3}$ or its calcination prior to a leaching with solutions such as ammonia chloride can result in a residue with high REEs content. Although, the carbonation of PG demonstrated interesting improvement in terms of REE extraction, the main disadvantages remain the high reagent cost and energy consumption as well as the limited market for $\mathrm{CaCO}_{3}$ and AS, which is a common by-product in this process [61].

$$
\left(\mathrm{NH}_{4}\right)_{2} \mathrm{CO}_{3}+\mathrm{CaSO}_{4}=\left(\mathrm{NH}_{4}\right)_{2} \mathrm{SO}_{4}+\mathrm{CaCO}_{3}
$$

\subsubsection{Recrystallization}

REEs do not isomorphously cocrystallize with the lattice structure but rather exist in separate phases offering a good opportunity in terms of REE extraction and recrystallization of technically pure PG [73]. The dissolution and recrystallization of PG with attention to REE recovery is an emerging area of research and has been reported $[29,73]$. In view of this approach, a few trials have been performed both at laboratory scale and larger scale. For instance, Genkin et al. [73] described a process where PG-dehydrate was recrystallized in the presence of calcium nitrate (in terms of $\mathrm{Ca}^{2+}$ ) under acidic medium 
(0.2-8 M, in terms of $\left.\mathrm{H}^{+}\right)$. Subsequent to this method, over $98 \%$ of the REEs reported in the leaching solution. In this process, the solvent extraction method was suggested for subsequent recovery of REEs and further processing. Nevertheless, the proposed process was found to be unattractive from an economical and waste management point of view. Furthermore, although increased concentration of $\mathrm{Ca}^{2+}$ ions was favorable in terms of REE recovery, this increase made the formation of the targeted and purified PG less favourable. Another approach described by Koopman and Witkamp [29] consisted of introducing an ion-exchange resin for the extraction and recovery of REEs leached out during the recrystallization of PG-hemidihydrate to PG-dehydrate. Their results revealed a significant decrease of REEs in the final PG-dehydrate residue and the amount of REE released during the recrystallization process was found to be up to 53\%. The authors indicated that REE extraction efficiency was mainly influenced by the recrystallization reaction but individual REEs that had a strong affinity to PG-dehydrate were least extracted. The main disadvantage of this process was that the sulfonic acid resin used also extracted calcium ions besides having a preference for trivalent REEs. A method developed at Mintek in Randburg, South Africa by Yahorava et al. [61] entailed hydrothermally treating PG containing slurry using an autoclave for the recrystallization and recovery of REEs. The process was tested on various PG samples and showed that REE recoveries were improved from 5\% to $80 \%$ while recrystallizing the PG. Although the process carried a large potential for unlocking valuable REEs encapsulated in PG stock piles, there were still several parameters such as residence time in the autoclave, impact of seeding and solids content which required verification and optimization. Moreover, even though the process claimed to be "chemical free", temperatures of up to $100{ }^{\circ} \mathrm{C}$ were required in the autoclave for high release of REEs during the recrystallization process. Similarly, the method developed at Integra.Ru Co Ltd. in Moscow, Russia by Kanzel et al. [74] consisted of decomposing PG while extracting released REEs using sulphuric acid in five consecutive stages. The resulting solid residue (cake) was technically a gypsum that could be used in the production of building materials (e.i. binders) and the liquid waste which was technically an industrial water contained high concentrations of REEs that were subsequently extracted using standard methods at a purity of $99 \%$. However, the production of gypsum from PG in such a process is an energy intensive process since the PG binder is burned at higher temperatures than are traditionally used to obtain a binder from natural gypsum stone, hence making the proposed process economically unprofitable particularly when considering large scale processing $[75,76]$.

The synthesis of calcium sulphate whiskers (CSWs) from PG due to high content of $\mathrm{CaSO}_{4}$ is also an emerging area of research and has been recently discussed $[77,78]$. CSWs have been widely used for several applications such as reinforcing materials in plastics, paper mills, rubbers, grafting materials in bone and tissue regeneration, filters, paints and other products $[79,80]$. So far, efforts in this area have been made following three directions namely: the synthesis, modification of the crystal morphologies using additives, and the application of CSWs for constructional materials [81]. However, little effort has been made to develop a combined process in which both the synthesis of CSWs and REEs extraction could be sequentially achieved. CSWs are typically prepared through hydrothermal or atmospheric acidification synthesis or recrystallization. Compared to the hydrothermal synthesis, which is usually carried at high temperatures $\left(>100^{\circ} \mathrm{C}\right)$ and steam pressures [82], the atmospheric acidification of PG has advantages since it can be carried out at a mild reaction conditions (temperature $<90{ }^{\circ} \mathrm{C}$ and atmospheric pressure) [78]. Figure 3 shows a proposed flow diagram of this process with a subsequent extraction of REEs. 


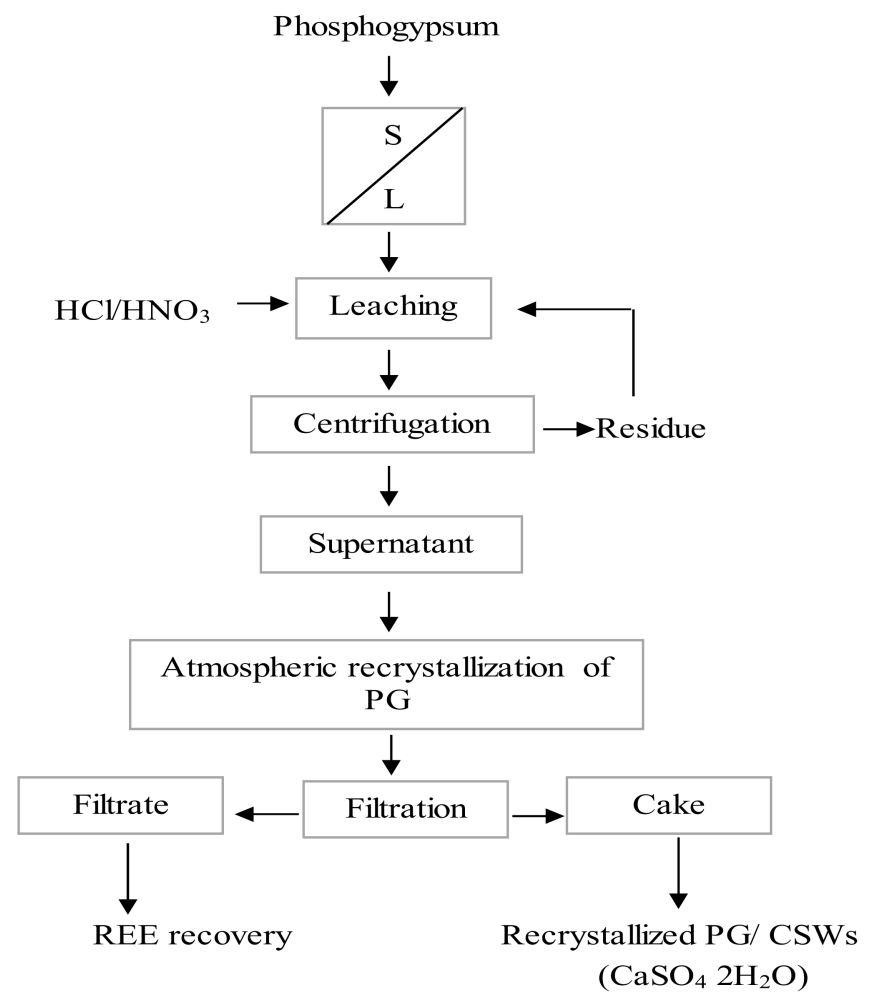

Figure 3. Proposed flowsheet of an atmospheric acid recrystallization of PG with subsequent extraction of REEs.

\subsection{Organic Liquid}

REE leaching using organic solvents has also been discussed in the literature. This approach is referred to as solvometallurgy in comparison to hydrometallurgy where mineral acids are usually used. The solvometallurgical method allows a high selectivity of metals to be obtained and reduces both the consumption of acids and the volumes of leaching solutions [24,83]. A recent method proposed by El-Didamony et al. [72,84] aimed to remove the radioactive elements such as radium, uranium, thorium, cadmium, chromium etc. from PG while recovering REEs simultaneously using an organic solution of tri- $n$-butyl phosphate (TBP), tri- $n$-octylphosphine oxide (TOPO) and a mixture of TBP + TOPO in kerosene. The results revealed leaching efficiencies of between $66 \%$ and $73 \%$ for radioactive metals and $69 \%$ of total REEs when leaching PG with $0.5 \mathrm{M}$ TBP using S:L ratio of 1 for $2 \mathrm{~h}$ at $55^{\circ} \mathrm{C}$. Two successive leaching steps were found to increase the removal efficiencies of both radioactive elements and REE metals while a third step did not bring any further enhancement. However, in the case of successive steps using a mixture of organic solutions namely TBP and TOPO with molar concentrations of 0.7 and 0.9 , respectively, a considerable increase was obtained. Further investigation showed that pre-treating PG with hot sodium carbonate $(0.5 \mathrm{M})$ prior to a leaching with a mixture of TBP and TOPO in kerosene had a significant effect on the extractability of these elements with an optimal removal efficiency of $94.6 \%$ and $80.1 \%$ that were achieved for radioactive elements and REE recovery, respectively. Although organic solvents have demonstrated relatively high recovery of REEs and other metals present in PG, the loss of organic reagents that were generally adsorbed and entered into the matrix of gypsum may lead to high costs due to the amount of organic solvents used as well as environmental concerns. Organic leaching processes are therefore promising but require more research and development before they can be implemented at a large scale. 


\subsection{Bioleaching}

Bioleaching for metal extraction is an emerging technology, which is currently considered among other approaches to overcome some of the disadvantages encountered in direct leaching such as high operational cost, generation of both heavy metal pollution and sludge, and poor recovery [85-87]. Bioleaching processes can be performed by autotrophic or heterotrophic microorganisms and the selection of the latter depends on the type of the bearing mineral. Heterotrophic microorganisms have mostly been reported in the literature for REE extraction via bioleaching and includes the production of organic acids and metal-binding molecules [88]. The organic acids, namely oxalic, gluconic, acetic, citric, formic and malic acids decrease the $\mathrm{pH}$ allowing the leaching of REE while the metal-binding molecules act as chelating agent for separation of the targeted molecule out of the solution $[61,87,89]$. Bioleaching processes are relatively slow, most occur at lower pressures and temperatures and do not require the utilization of aggressive reagents [88]. Bioleaching has mostly been reported for REE extraction from other secondary REE sources such as bauxite but only a little information is available for PG. Bioleaching of PG for REE recovery is usually achieved using either anaerobic or aerobic microorganism species such as Gluconobacter, Acidithiobacillus, Acetobacter or Desulfivibrio and can be achieved through column or heap leaching processes $[87,89]$. Phosphate-solubilizing microorganisms (PSMs) have also been reported and used to solubilize the REEs from various bearing minerals [87]. Bacterial species such as Pseudomonas, Bacillus, Rhizobium, Erwinia, Agrobacterium, Flavobacterium, Enterobacter, Micrococcus, Thiobacillus Acetobacter, Clavibacter, Serratia, and Streptomyces as well as some fungi such as Penicillium, Aspergillus, Rhizopus, and Fusarium have been found to be efficient in bioleaching processes using PSMs [89]. According to Glombitza and Reichel [90], mineral dissolution in bioleaching may proceed via one or several mechanisms which mainly include (a) complexation promoted dissolution (complexolysis), (b) proton promoted dissolution (acidolysis) and (c) redox reactions (redoxolysis). In these mechanisms, microorganisms produce metabolites by changing the $\mathrm{pH}$ of their surroundings and the formed metabolites form in turn complexes with the metals and therefore lead to their mobilization from solids (complexolysis). The dissolution of the solids (acidolysis) can similarly occur at reduced $\mathrm{pH}$. The aforementioned mechanisms are systematically explained in Figure 4 where seven scenarios are expected to take place for bioleaching of REEs.

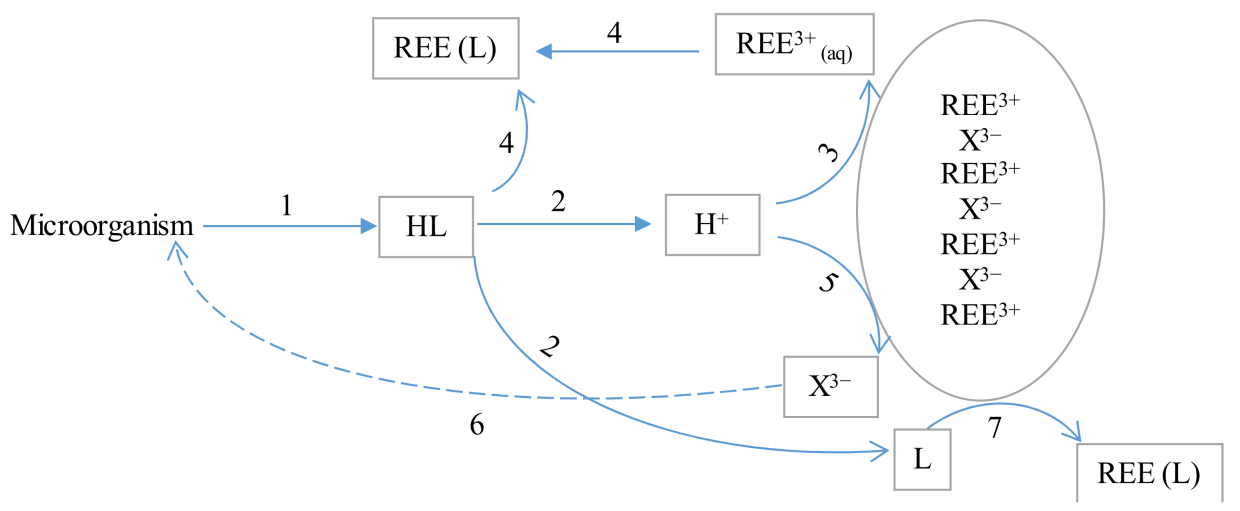

Figure 4. Possible mechanisms and reactions of REE bioleaching where (1) ligand (L) is secreted, (2) ligand dissociates, (3) proton promoted dissolution due to reaction with $\mathrm{REE}^{3+}$, (4) reaction of $\operatorname{REE}^{3+}$ (aq) with ligand protonated (HL), (5) dissolution of proton promoted due to reaction with arbitrary anion $\left(\mathrm{X}^{3-}\right)$, (6) $\mathrm{X}^{3-}$ up taking by microorganism, and (7) dissolution of ligand promoted. Adapted from [91].

A study by Barmettler et al. [92], has showed that a mixed culture of sulphur-oxidizing bacteria was able to extract $55-70 \%$ of REEs from PG after 30 days of incubation at $\mathrm{pH}$ 1.5-1.8. The authors attributed this leaching of REEs to the sulphuric acid generated by 
sulphur-oxidizing bacteria. In another trial, where a sulfate-reducing bacteria Disulfovibrio desulfuricans was used, about $80 \%$ extraction was achieved for yttrium using a fixedbed reactor. The ability of a gluconic acid dominated biolixiviant was also examined by Antonick et al. [53], conventional for the extraction of REEs from synthetic PG. The results indicated that although this biolixiviant was more effective for REE leaching compared to a commercial gluconic acid, its performance was very low in comparison with conventional $\mathrm{H}_{2} \mathrm{SO}_{4}$ acid leaching. The authors suggested more trials on real PG. However, more studies with regard to the costing and environmental impacts associated are still needed to decide whether or not bioleaching is a suitable option for REE recovery from industrial PG [92]. Compared to chemical leaching which uses strong acids (inorganic or organic) and complexants, bioleaching suffers from lower yield and rates [91]. The effectiveness of this process mainly depends on the ability of the microorganisms to oxidize and thus to leach the REEs and also on parameters such as particle size of the REE bearing mineral, the $\mathrm{pH}$ of the leaching media and the temperature [93].

Table 4 gives a comparative overview of various methods discussed in Section 4 of this review with particular attention to their advantages and disadvantages. Among other approaches, the atmospheric acid recrystallization of PG was found to be more promising as it can allow REE recovery and CSWs to be obtained separately and subsequently for both small and large scale.

Table 4. Overview of the advantages and disadvantages of the approaches discussed in this review.

\begin{tabular}{|c|c|c|}
\hline Approach & Advantages & Disadvantages \\
\hline Direct acid leaching & $\begin{array}{ll}\text { - } & \text { High efficiencies } \\
\text { - } & \text { Applicable at small and large scale } \\
\text { - No specific equipment required }\end{array}$ & $\begin{array}{ll}\text { - } & \text { High acid concentrations required } \\
\text { - } & \text { Generally uneconomical for large scale } \\
\text { Not environmentally benign }\end{array}$ \\
\hline Organic liquid & $\begin{array}{ll}\text { - } & \text { Selective } \\
\text { - } & \text { No specific equipment required } \\
\text { Mostly applicable at small scale }\end{array}$ & $\begin{array}{l}\text { - Loss of organic reagents generally adsorbed } \\
\text { into the matrix of gypsum } \\
\text { - } \quad \text { High cost of organic solvents } \\
\text { - Still required more research for large scale }\end{array}$ \\
\hline Bioleaching & $\begin{array}{l}\text { - No harsh conditions (temperatures) required } \\
\text { - } \quad \text { No specific equipment required } \\
\text { - } \quad \text { Environmentally safe }\end{array}$ & $\begin{array}{l}\text { - Low yields/rates } \\
\text { - } \quad \text { Eequired several hours/days } \\
\text { microorganisms to oxidize phosphogypsum } \\
\text { particle }\end{array}$ \\
\hline Carbonation & $\begin{array}{l}\text { - } \quad \text { Allows obtaining a carbonate reach in REEs } \\
\text { - } \quad \text { Specific equipment (reactor) required } \\
\text { Can be used at small/large scale }\end{array}$ & $\begin{array}{l}\text { - } \quad \text { High reagent cost } \\
\text { - } \quad \text { High energy consumption } \\
\text { Dissolution of carbonates required for REE } \\
\text { recovery } \\
\text { Generation of additional by-products such as } \\
\text { ammonia sulphate }\end{array}$ \\
\hline Atmospheric recrystallization & $\begin{array}{l}\text { - } \\
\text { - } \quad \text { Mllows obtaining both REE and calcium } \\
\text { - } \quad \text { Can be achieved in a loop system } \\
\text { - } \quad \text { No specific equipment required } \\
\text { - } \quad \text { Can be used at small/large scale }\end{array}$ & $\begin{array}{l}\text { - } \quad \text { Use of acids required } \\
\text { REE recovery required solvent extraction or } \\
\text { precipitation step }\end{array}$ \\
\hline
\end{tabular}

\section{Methods of REE Recovery}

The recovery of REE from PG leachates is usually carried out using common techniques as those developed for primary sourced REEs [28]. Methods such as precipitation, liquid-liquid extraction (solvent extraction), solid-liquid extraction (adsorption) and ionexchange have widely been used for separation and purification since PG leachate is obtained as a mixture of REEs alongside with other metals. These methods are generally used in an attempt to produce REEs in a suitable form and purity. The ion-exchange consists of adsorbing REE ions from the leachates onto an exchanger that is specific and 
selective for REEs. In a reverse process, REE ions are desorbed from the exchanger during an elution step [94]. The ion-exchange method has been used for decades and is highly selective. However, its cost limits its use except in certain processes where the production of extremely pure materials is required [3,95]. Similar to ion-exchange, solvent extraction, also known as liquid-liquid extraction, is highly selective and has the advantage over the ion-exchange method because it is fast, cost effective and can be used in a continuous process where large volumes of leachates are required. Solvent extraction is therefore the most commonly used commercial method for separation and purification of REEs from acid solutions [3]. Another emerging method for REE separation and purification is solid-liquid extraction. This method uses nanoporous materials such as polymeric fibres, or silica and carbon based sorbents to separate and purify the REEs [94,96]. In a recent study by Hu et al. [95], silica and carbon-based sorbents were reported for REE separation and purification. Their results highlighted four main aspects that were satisfactory namely a high enrichment factor, rapid adsorption kinetics, reduced solvent use and minimized waste generation obtained.

\section{Conclusions}

REEs are a critical and strategic resource of the modern world and to meet the growing industrial and technological needs, alternative secondary sources of REEs such as PG residues are continuously being explored worldwide. This review highlighted the research progress on various efficient leaching processes for the recovery of REEs from PG. This review provided information about the leaching of PG to provide an overview for the recovery of REEs contained in secondary wastes as critical raw materials. The first stage in REE recovery from waste materials is the leaching of elements from the solids. This knowledge is required in subsequent hydrometallurgical processing steps to recover REEs contained in these wastes. Direct leaching of PG for REE extraction using inorganic, organic and microorganisms is uneconomical and failed in most cases for large scale processing due to low concentration of REEs compared to other metal constituents in PG. Therefore, combining both REE extraction and subsequent recrystallization of PG for the synthesis of useful industrial materials such as calcium whiskers (CSWs) is a promising approach and could be feasible at small scale and large scale. Such a combination offers the possibility for exploitation of a secondary waste source of REEs, which may have a great impact on the economies of countries where primary sources of REEs are lacking. Furthermore, compared to the carbonation process which required dissolution of the carbonate reach in REEs, the recrystallization of PG offers the opportunity to extract the REEs directly from the filtrate.

Author Contributions: Conceptualization and writing-original draft preparation were carried out by J.-L.M.; C.P.E. and O.P. contributed with supplementarys of the review; supervision, funding acquisition and editing by L.F.P. All authors have read and agreed to the published version of the manuscript.

Funding: The authors would like to thank the Water Research commission (WRC) of South Africa for funding the research project through WRC K5/2483.

Data Availability Statement: Not applicable.

Acknowledgments: The authors acknowledge the funding from the Water Research Commission (WRC) of South Africa and express their appreciation for the academic support of the Environmental and Nano Sciences (ENS) research group at the University of the Western Cape (South Africa).

Conflicts of Interest: The authors declare no conflict of interest.

\section{References}

1. Dushyantha, N.; Batapola, N.; Ilankoon, I.M.S.K.; Rohitha, S.; Premasiri, R.; Abeysinghe, B.; Ratnayake, N.; Dissanayake, K. The story of rare earth elements (REEs): Occurrences, global distribution, genesis, geology, mineralogy and global production. Ore Geol. Rev. 2020, 122, 103521. [CrossRef]

2. Golev, A.; Scott, M.; Erskine, P.D.; Ali, S.H.; Ballantyne, G.R. Rare earths supply chains: Current status, constraints and opportunities. Res. Policy 2014, 41, 52-59. [CrossRef] 
3. Peiravi, M.; Dehghani, F.; Ackah, L.; Baharlouei, A.; Godbold, J.; Liu, J.; Mohanty, M.; Ghosh, T. A Review of Rare-Earth Elements Extraction with Emphasis on Non-Conventional Sources: Coal and Coal by products, Iron Ore Tailings, Apatite, and Phosphate by products. Min. Metal. Explor. 2021, 38, 1-26.

4. Goodenough, K.M.; Wall, F.; Merriman, D. The rare earth elements: Demand, global resources, and challenges for resourcing future generations. Nat. Resour. Res. 2018, 27, 201-216. [CrossRef]

5. Mancheri, N.A.; Sprecher, B.; Bailey, G.; Ge, J.; Tukker, A. Effect of Chinese policies on rare earth supply chain resilience. Res. Conserv. Recycl. 2019, 142, 101-112. [CrossRef]

6. Jha, M.K.; Kumari, A.; Panda, R.; Kumar, J.R.; Yoo, K.; Lee, J.Y. Review on hydrometallurgical recovery of rare earth metals. Hydrometallurgy 2016, 165, 2-26. [CrossRef]

7. Tunsu, C.; Petranikova, M.; Gergorić, M.; Ekberg, C.; Retegan, T. Reclaiming rare earth elements from end-of-life products: A review of the perspectives for urban mining using hydrometallurgical unit operations. Hydrometallurgy 2015, 156, 239-258. [CrossRef]

8. Jordens, A.; Cheng, Y.P.; Waters, K.E. A review of the beneficiation of rare earth element bearing minerals. Miner. Eng. 2013, 41, 97-114. [CrossRef]

9. Blissett, R.S.; Smalley, N.; Rowson, N.A. An investigation into six coal fly ashes from the United Kingdom and Poland to evaluate rare earth element content. Fuel 2014, 119, 236-239. [CrossRef]

10. Seredin, V.V.; Dai, S.; Sun, Y.; Chekryzhov, I.Y. Coal deposits as promising sources of rare metals for alternative power and energy-efficient technologies. Appl. Geochem. 2013, 31, 1-11. [CrossRef]

11. Cánovas, C.R.; Chapron, S.; Arrachart, G.; Pellet-Rostaing, S. Leaching of rare earth elements (REEs) and impurities from phosphogypsum: A preliminary insight for further recovery of critical raw materials. J. Clean. Prod. 2019, 219, 225-235. [CrossRef]

12. McLellan, B.C.; Corder, G.D.; Ali, S.H. Sustainability of rare earths-An overview of the state of knowledge. Minerals 2013, 3 , 304-317. [CrossRef]

13. Binnemans, K.; Jones, P.T.; Blanpain, B.; Van Gerven, T.; Yang, Y.; Walton, A.; Buchert, M. Recycling of rare earths: A critical review. J. Clean. Prod. 2013, 51,1-22. [CrossRef]

14. Innocenzi, V.; De Michelis, I.; Kopacek, B.; Veglio, F. Yttrium recovery from primary and secondary sources: A review of main hydrometallurgical processes. Waste Manag. 2014, 34, 1237-1250. [CrossRef]

15. Canovas, C.R.; Perez-Lopez, R.; Macías, F.; Chapron, S.; Nieto, J.M.; Pellet-Rostaing, S. Exploration of fertilizer industry wastes as potential source of critical raw materials. J. Clean. Prod. 2017, 143, 497-505. [CrossRef]

16. Kulczycka, J.; Kowalski, Z.; Smol, M.; Wirth, H. Evaluation of the recovery of rare earth elements (REE) from phosphogypsum waste case study of the WIZOW chemical plant (Poland). J. Clean. Prod. 2016, 113, 345-354. [CrossRef]

17. Rychkov, V.N.; Kirillov, E.V.; Kirillov, S.V.; Semenishchev, V.S.; Bunkov, G.M.; Botalov, M.S.; Smyshlyaev, D.V.; Malyshev, A.S. Recovery of rare earth elements from phosphogypsum. J. Clean. Prod. 2018, 196, 674-681. [CrossRef]

18. Brückner, L.; Elwert, T.; Schirmer, T. Extraction of rare earth elements from phosphogypsum: Concentrate digestion, leaching, and purification. Metals 2020, 10, 131. [CrossRef]

19. $\mathrm{Li}, \mathrm{X}$.; $\mathrm{Wu}, \mathrm{P}$. Geochemical characteristics of dissolved rare earth elements in acid mine drainage from abandoned high-As coal mining area, southwestern China. Environ. Sci. Pollut. Res. 2017, 24, 20540-20555. [CrossRef]

20. Pan, J.; Zhou, C.; Liu, C.; Tang, M.; Cao, S.; Hu, T.; Ji, W.; Luo, Y.; Wen, M.; Zhang, N. Modes of occurrence of rare earth elements in coal fly ash: A case study. Energy Fuels 2018, 32, 9738-9743. [CrossRef]

21. Peelman, S.; Kooijman, D.; Sietsma, J.; Yang, Y. Hydrometallurgical recovery of rare earth elements from mine tailings and WEEE. J. Sustain. Met. 2018, 4, 367-377. [CrossRef]

22. Vander Hoogerstraete, T.; Blanpain, B.; Van Gerven, T.; Binnemans, K. From NdFeB magnets towards the rare-earth oxides: A recycling process consuming only oxalic acid. RSC Adv. 2014, 4, 64099-64111. [CrossRef]

23. Maroufi, S.; Nekouei, R.K.; Hossain, R.; Assefi, M.; Sahajwalla, V. Recovery of rare earth (i.e., La, Ce, Nd, and Pr) oxides from end-of-life Ni-MH battery via thermal isolation. ACS Sustain. Chem. Eng. 2018, 6, 11811-11818. [CrossRef]

24. Binnemans, K.; Jones, B.; Blanpain, T.; Van Gerven, Y.; Pontikes, Y. Towards zerowaste valorisation of rare-earth-containing industrial process residues: A critical review. J. Clean. Prod. 2015, 99, 17-38. [CrossRef]

25. Innocenzi, V.; Ippolito, N.M.; Pietrelli, L.; Centofanti, M.; Piga, L.; Veglio, F. Application of solvent extraction operation to recover rare earths from fluorescent lamps. J. Clean. Prod. 2018, 172, 2840-2852. [CrossRef]

26. Roszczynialski, W.; Gawlicki, M.; Nocun-Wczelik, W. Production and use of by-product gypsum in the construction industry. In Waste Materials Used in Concrete Manufacturing; William Andrew Publishing: Norwich, NY, USA, 1996; pp. 53-141.

27. Rutherford, P.M.; Dudas, M.J.; Samek, R.A. Environmental impacts of phosphogypsum. Sci. Total Environ. 1994, 149, 1-38. [CrossRef]

28. Wu, S.; Zhao, L.; Wang, L.; Huang, X.; Zhang, Y.; Feng, Z.; Cui, D. Simultaneous recovery of rare earth elements and phosphorus from phosphate rock by phosphoric acid leaching and selective precipitation: Towards green process. J. Rare Earths 2019, 37 , 652-658. [CrossRef]

29. Koopman, C.; Witkamp, G.J. Extraction of lanthanides from the phosphoric acid production process to gain a purified gypsum and a valuable lanthanide by-product. Hydrometallurgy 2000, 58, 51-60. [CrossRef]

30. Al-Thyabat, S.; Zhang, P. REE extraction from phosphoric acid, phosphoric acid sludge, and phosphogypsum. Min. Proc. Ext. Met. 2015, 124, 143-150. [CrossRef] 
31. Santos, A.; Mazzilli, B.; Fávaro, D.; Silva, P. Partitioning of radionuclides and trace elements in phosphogypsum and its source materials based on sequential extraction methods. J. Environ. Radioactiv. 2006, 87, 52-61. [CrossRef]

32. Walawalkar, M.; Nichol, C.K.; Gisele Azimi, G. Process Investigation of the Acid Leaching of Rare Earth Elements from Phosphogypsum Using HCl, HNO3 and H2SO4. Hydrometallurgy 2016, 166, 195-204. [CrossRef]

33. Ismail, Z.; Abu Elgoud, E.; Gasser, M.; Aly, H.; Abdel Hai, F.; Ali, I. Leaching of some lanthanides from phosphogypsum fertilizers by mineral acids. Arab J. Nucl. Sci. Appl. 2015, 48, 37-50.

34. Lokshin, E.; Tareeva, O.; Elizarova, I. On integrated processing of phosphogypsum, Russ. J. Appl. Chem. 2013, 86, 463-468.

35. Kybartiene, N.; Valancius, Z.; Leskeviciene, V.; Urbonas, L. Influence of the composition of phosphate rock on the amount of water-insoluble phosphate impurities in semi-hydrate phosphogypsum. Ceram.-Silikáty 2015, 59, $29-36$.

36. Samonov, A. New data on mineral forms of rare metals in phosphogypsum wastes. In Doklady Earth Sciences; Springer: Berlin/Heidelberg, Germany, 2011; Volume 440, pp. 1312-1315.

37. Hammas-Nasri, I.; Horchani-Naifer, K.; Férid, M.; Barca, D. Rare earths concentration from phosphogypsum waste by two-step leaching method. Int. J. Miner. Process. 2016, 149, 78-83. [CrossRef]

38. Li, X.; Zhou, Z.; Zhao, G.; Liu, Z. Utilization of phosphogypsum for backfilling, way to relieve its environmental impact. Gospod. Surowcami Miner. 2008, 24, 226-232.

39. Oliveira, S.M.B.; Da Silva, P.S.C.; Mazzilli, B.P.; Favaro, D.I.T.; Saueia, C.H. Rare earth elements as tracers of sediment contamination by phosphogypsum in the Santos estuary, southern Brazil. Appl. Geochem. 2007, 22, 837-850. [CrossRef]

40. Fuleihan, N.F. Phosphogypsum disposal-the pros \& cons of wet versus dry stacking. Procedia Eng. 2012, 46, $195-205$.

41. Oliveira, K.; Menezes, M.; Von Sperling, E.; Jacomino, V. Transfer factor of rare earth elements from phosphogypsum amended Brazilian tropical soils to lettuce, corn and soybean. J. Solid Waste Technol. Manag. 2012, 38, 202-210. [CrossRef]

42. Tayibi, H.; Choura, M.; López, F.A.; Alguacil, F.J.; López-Delgado, A. Environmental impact and management of phosphogypsum. J. Environ. Manag. 2009, 90, 2377-2386. [CrossRef]

43. Masmoudi-Soussi, A.; Hammas-Nasri, I.; Horchani-Naifer, K.; Ferid, M. Study of rare earths leaching after hydrothermal conversion of phosphogypsum. Chem. Afr. 2019, 2, 415-422. [CrossRef]

44. Dutrizac, J.E. The Behaviour of the Rare Earth Elements during Gypsum $\left(\mathrm{CaSO} 4 \cdot 2 \mathrm{H}_{2} \mathrm{O}\right)$ Precipitation. Hydrometallurgy 2017, 174, 38-46. [CrossRef]

45. Borges, R.C.; Favaro, D.I.T.; Caldas, V.G.; Lauria, D.C.; Bernedo, A.V.B. Instrumental Neutron Activation Analysis, Gamma Spectrometry and Geographic Information System Techniques in the Determination and Mapping of Rare Earth Element in Phosphogypsum Stacks. Environ. Earth Sci. 2016, 75, 705. [CrossRef]

46. Yang, X.; Salvador, D.; Makkonen, H.T.; Pakkanen, L. Phosphogypsum processing for rare earths recovery-A review. Nat. Resour. 2019, 10, 325. [CrossRef]

47. Yang, X.; Makkonen, H.T.; Pakkanen, L. Rare Earth Occurrences in Streams of Processing a Phosphate Ore. Minerals 2019, 9, 262. [CrossRef]

48. Yang, J. Reprocessing of Phosphogypsum for Recovery of REE. In Proceedings of the Prometia Scientific Seminar, Barcelona, Spain, 28-29 November 2017; pp. 28-29.

49. Reid, S.; Walawalkari, M.; Azimi, G. Valorization of Rare Earth-Containing Landfilled Stocks of Industrial Process Residues: Phosphogypsum and Red Mud. In Proceedings of the The European Real Estate Society (ERES), Santorini, Greece, 28-31 May 2017; pp. 164-165.

50. Lambert, A.; Anawati, J.; Walawalkar, M.; Tam, J.; Azimi, G. Innovative application of microwave treatment for recovering of rare earth elements from phosphogypsum. ACS Sustain. Chem. Eng. 2018, 6, 16471-16481. [CrossRef]

51. Hammas-Nasri, I.; Horchani-Naifer, K.; Férid, M.; Barca, D. Production of a rare earths concentrate after phosphogypsum treatment with dietary $\mathrm{NaCl}$ and $\mathrm{Na} 2 \mathrm{CO} 3$ solutions. Miner. Eng. 2019, 132, 169-174. [CrossRef]

52. Jyothi, R.K.; Thenepalli, T.; Ahn, J.W.; Parhi, P.K.; Chung, K.W.; Lee, J.Y. Review of rare earth elements recovery from secondary resources for clean energy technologies: Grand opportunities to create wealth from waste. J. Clean. Prod. 2020, 267, 122048. [CrossRef]

53. Antonick, P.J.; Hu, Z.; Fujita, Y.; Reed, D.W.; Das, G.; Wu, L.; Shivaramaiah, R.; Kim, P.; Eslamimanesh, A.; Lencka, M.M.; et al. Bio-and mineral acid leaching of rare earth elements from synthetic phosphogypsum. J. Chem. Thermodyn. 2019, 132, 491-496. [CrossRef]

54. Kouraim, M.N.; Fawzy, M.M.; Helaly, O.S. Leaching of lanthanides from phosphogypsum waste using nonyl phenol ethoxylate associated with $\mathrm{HNO}_{3}$ and $\mathrm{HCl}$. Int. J. Sci. Basic Appl. Res. 2014, 16, 31-44.

55. Liang, H.; Zhang, P.; Jin, Z.; DePaoli, D. Rare earths recovery and gypsum upgrade from Florida phosphogypsum. Miner. Metall. Process. 2017, 34, 201-206. [CrossRef]

56. Lokshin, E.; Tareeva, O.; Elizarova, I. A study of the sulfuric acid leaching of rare-earth elements, phosphorus, and alkali metals from phosphodihydrate. Russ. J. Appl. Chem. 2010, 83, 958-964. [CrossRef]

57. Valkov, A.V.; Andreev, V.A.; Anufrieva, A.V.; Makaseev, Y.N.; Bezrukova, S.A.; Demyanenko, N.V. Phosphogypsum Technology with the Extraction of Valuable Components. Procedia Chem. 2014, 11, 176-181. [CrossRef]

58. El-Reefy, S.; Nayl, A.; Aly, H. Leaching and group separation of lanthanides from phosphogypsum. In Proceedings of the 9th. International Conference for Nuclear Sciences and Applications, Sharm Al Sheikh, Egypt, 11-14 February 2008; pp. 11-14. 
59. Lokshin, E.; Vershkova, Y.A.; Vershkov, A.; Tareeva, O. Leaching of lanthanides from phosphohemihydrate with nitric acid. Russ. J. Appl. Chem. 2002, 75, 1753-1759. [CrossRef]

60. Salo, M.; Knauf, O.; Mäkinen, J.; Yang, X.; Koukkari, P. Integrated acid leaching and biological sulfate reduction of phosphogypsum for REE recovery. Miner. Eng. 2020, 155, 106408. [CrossRef]

61. Yahorava, V.; Bazhko, V.; Freeman, M. Viability of phosphogypsum as a secondary resource of rare earth elements. In Proceedings of the XXVIII International Mineral Processing Congress Proceedings, Quebec City, QC, Canada, 11-15 September 2016; pp. 1-16, ISBN 9781926872292.

62. Kolokolnikov, V.A.; Kovalev, M.I. Technology for processing technical calcium carbonate obtained from phosphogypsum into pure calcium carbonate and rare-earth element concentrate. Chem. Sustain. Dev. 2009, 17, 387-393.

63. De Beer, M.; Maree, J.P.; Liebenberg, L.; Doucet, F.J. Conversion of calcium sulphide to calcium carbonate during the process of recovery of elemental sulphur from gypsum waste. Waste Manag. 2014, 34, 2373-2381. [CrossRef] [PubMed]

64. Kandil, A.H.T.; Cheira, M.F.; Gado, H.S.; Soliman, M.H.; Akl, H.M. Ammonium sulfate prepar tion from phosphogypsum waste. J. Radiat. Res. Appl. Sci. 2017, 10, 24-33. [CrossRef]

65. Safiulina, A.M.; Matveeva, A.G.; Evtushenko, A.V.; Lizunov, A.V.; Goryunov, E.I.; Goryunova, I.B.; Brel, V.K. Recovery of lanthanides from digested phosphogypsum solutions using a new organophosphorus extractant, 5-(diphenylphosphoryl) hexan-3-one. Russ. J. Gen. Chem. 2015, 85, 2128-2134. [CrossRef]

66. Mattila, H.P.; Zevenhoven, R. Mineral carbonation of phosphogypsum waste for production of useful carbonate and sulfate salts. Front. Energy Res. 2015, 3, 48. [CrossRef]

67. Masmoudi-Soussi, A.; Hammas-Nasri, I.; Horchani-Naifer, K.; Ferid, M. Rare earths recovery by fractional precipitation from a sulfuric leach liquor obtained after phosphogypsum processing. Hydrometallurgy 2020, 191, 105253. [CrossRef]

68. Laurino, J.P.; Mustacato, J.; Huba, Z.J. Rare earth element recovery from acidic extracts of Florida phosphate mining materials using chelating polymer 1-octadecene, polymer with 2,5-furandione sodium salt. Minerals 2019, 9, 477. [CrossRef]

69. Grabas, K.; Pawelczyk, A.; Strek, W.; Szeleg, E.; Strek, S. Study on the properties of waste apatite phosphogypsum as a raw material of prospective application. Waste Biomass Valor. 2019, 10, 3143-3155. [CrossRef]

70. Virolainen, S.; Repo, E.; Sainio, T. Recovering rare earth elements from phosphogypsum using a resin-in-leach process: Selection of resin, leaching agent, and eluent. Hydrometallurgy 2019, 189, 105125. [CrossRef]

71. Gasser, M.S.; Ismail, Z.H.; Abu Elgoud, A.; Abdel Hai, F.; Ali, O.I.; Aly, H.F. Process for Lanthanides-Y leaching from phosphogypsum fertilizers using weak acids. J. Hazard. Mater. 2019, 378, 12762. [CrossRef] [PubMed]

72. El-Didamony, H.; Ali, M.M.; Awwad, N.S.; Fawzy, M.M.; Attallah, M.F. Treatment of phosphogypsum waste using suitable organic extractants. J. Radioanal. Nucl. Chem. 2012, 291, 907-914. [CrossRef] [PubMed]

73. Genkin, M.V.; Evtushenko, A.V.; Komkov, A.A.; Safiulina, A.M.; Spiridonov, V.S.; Shvetsov, S.V.; Uralchem, J.S.C. Methods for Extracting Rare-Earth Metals and Preparing Gypsum Plaster from Phosphogypsum Hemihydrate. U.S. Patent 9,657,371, 25 April 2017.

74. Kanzel, A.V.; Mazurkevich, P.A.; Bortkov, I.A.; Hares, N.K. Method for Complex Processing of Phosphogypsum. Patent RU 2639394, 30 December 2017.

75. Bouchhima, L.; Rouis, M.J.; Choura, M. A study of phosphogypsum-crushing sand based bricks grade negligible weathering. Rom. J. Mater. 2017, 47, 316-323.

76. Campos, M.P.; Costa, L.J.P.; Nisti, M.B.; Mazzilli, B.P. Phosphogypsum recycling in the building materials industry: Assessment of the radon exhalation rate. J. Environ. Radioact. 2017, 1, 232-236. [CrossRef]

77. Sheng, Z.; Zhou, J.; Shu, Z.; Yakubu, Y.; Chen, Y.; Wang, W.; Wang, Y. Calcium sulfate whisker reinforced non-fired ceramic tiles prepared from phosphogypsum. Boletín Soc. Española Cerámica Vidr. 2018, 57, 73-78. [CrossRef]

78. Sun, H.; Tan, D.; Peng, T.; Liang, Y. Preparation of calcium sulfate whisker by atmospheric acidification method from flue gas desulfurization gypsum. Procedia Environ. Sci. 2016, 31, 621-626. [CrossRef]

79. Miao, M.; Feng, X.; Wang, G.; Cao, S.; Shi, W.; Shi, L. Direct transformation of FGD gypsum to calcium sulfate hemihydrate whiskers: Preparation, simulations, and process analysis. Particuology 2015, 19, 53-59. [CrossRef]

80. Qi, Y.; Zeng, C.; Wang, C.; Ke, X.; Zhang, L. Continuous fabrication of calcium sulfate whiskers with adjustable aspect ratio in microdroplets. Mater. Lett. 2017, 194, 231-233. [CrossRef]

81. Wang, X.; Wang, L.; Wang, Y.; Tan, R.; Ke, X.; Zhou, X.; Geng, J.; Hou, H.; Zhou, M. Calcium sulfate hemihydrate whiskers obtained from flue gas desulfurization gypsum and used for the adsorption removal of lead. Crystals 2017, 7, 270. [CrossRef]

82. Zhou, D.; Wei, R.; Zhu, Y.; Long, H.; Huang, B.; Wang, Y.; Wu, S. Calcium sulfate whisker one-step preparation using semi-dry flue gas desulfurization ash and directional growth control. J. Clean. Prod. 2021, 290, 125754. [CrossRef]

83. Canovas, C.R.; Macias, F.; Perez-Lopez, R.; Basallote, M.D.; Millan-Becerro, R. Valorization of wastes from the fertilizer industry: Current status and future trends. J. Clean. Prod. 2018, 174, 678-690. [CrossRef]

84. El-Didamony, H.; Gado, H.S.; Awwad, N.S.; Fawzy, M.M.; Attallah, M.F. Treatment of phosphogypsum waste produced from phosphate ore processing. J. Hazard. Mater. 2013, 244, 596-602. [CrossRef]

85. Pollmann, K.; Kutschke, S.; Matys, S.; Kostudis, S.; Hopfe, S.; Raff, J. Novel biotechnological approaches for the recovery of metals from primary and secondary resources. Minerals 2016, 6, 54. [CrossRef] 
86. Corbett, M.K.; Eksteen, J.J.; Niu, X.Z.; Croue, J.P.; Watkin, E.L.J. Interactions of phosphate solubilising microorganisms with natural rare-earth phosphate minerals: A study utilizing Western Australian monazite. Bioprocess Biosyst. Eng. 2017, 40, $929-942$. [CrossRef] [PubMed]

87. Hopfe, S.; Konsulke, S.; Barthen, R.; Lehmann, F.; Kutschke, S.; Pollmann, K. Screening and selection of technologically applicable microorganisms for recovery of rare earth elements from fluorescent powder. Waste Manag. 2018, 79, 554-563. [CrossRef] [PubMed]

88. Dev, S.; Sachan, A.; Dehghani, F.; Ghosh, T.; Briggs, B.R.; Aggarwal, S. Mechanisms of biological recovery of rare-earth elements from industrial and electronic wastes: A review. Chem. Eng. J. 2020, 397, 124596. [CrossRef]

89. Fathollahzadeh, H.; Eksteen, J.J.; Kaksonen, A.H.; Watkin, E.L.J. Role of microorganisms in bioleaching of rare earth elements from primary and secondary resources. Appl. Microbiol. Biotechnol. 2019, 103, 1043-1057. [CrossRef] [PubMed]

90. Glombitza, F.; Reichel, S. Metal-containing residues from industry and in the environment: Geobiotechnological urban mining. In Geobiotechnology I; Springer: Berlin/Heidelberg, Germany, 2013; pp. 49-107.

91. Rasoulnia, P.; Barthen, R.; Lakaniemi, A.M. A critical review of bioleaching of rare earth elements: The mechanisms and effect of process parameters. Crit. Rev. Environ. Sci. Technol. 2021, 51, 378-427. [CrossRef]

92. Barmettler, F.; Castelberg, C.; Fabbri, C.; Brandl, H. Microbial mobilization of rare earth elements (REE) from mineral solids-A mini review. AIMS Microbiol. 2016, 2, 190-204. [CrossRef]

93. Costis, S.; Mueller, K.K.; Coudert, L.; Neculita, C.M.; Reynier, N.; Blais, J.F. Recovery potential of rare earth elements from mining and industrial residues: A review and cases studies. J. Geochem. Explor. 2020, 221, 106699.

94. Pereao, O.; Bode-Aluko, C.; Fatoba, O.; Laatikainen, K.; Petrik, L. Rare earth elements removal techniques from water/wastewater: A review. Desalin. Water Treat 2018, 130, 71-86. [CrossRef]

95. Hu, Y.M.; Florek, J.; Lariviere, D.; Fontaine, F.G.; Kleitz, F. Recent Advances in the Separation of Rare Earth Elements Using Mesoporous Hybrid Materials. Chem. Rec. 2018, 18, 1261-1276. [CrossRef] [PubMed]

96. Hidayah, N.N.; Abidin, S.Z. The evolution of mineral processing in extraction of rare earth elements using solid-liquid extraction over liquid-liquid extraction: A review. Miner. Eng. 2017, 112, 103-113. [CrossRef] 